\title{
EARTHQUAKE LOSS ESTIMATION FOR REINFORCED CONCRETE BUILDINGS: SOME PROBLEMS
}

\author{
Robin SPENCE
}

Department of Architecture, University of Cambridge

Keywords: Reinforced concrete, earthquakes, ductility, loss estimation

\begin{abstract}
Capacity spectrum procedures developed for the assessment and strengthening of existing buildings have become the basis of methods for estimating potential post-earthquake losses which are today widely used in the insurance industry, and for urban risk mitigation programmes. The areas to which these methods are applied often contain (or largely consist of) reinforced concrete apartment buildings which were built either before today's "ductile" codes were introduced, or without benefit of them. However evidence from the performance of reinforced concrete structures in recent earthquakes indicates that failure very commonly occurs in a non-ductile manner which makes such calculated vulnerability approaches of questionable validity. On the other hand the alternative purely statistical approach to performance is unable to take account of many aspects of real building behaviour. The paper discusses the performance of reinforced concrete buildings in recent earthquakes and compares this with the assumptions of the calculated vulnerability models commonly in use.
\end{abstract}

\section{INTRODUCTION}

Experimental studies with reinforced concrete structures demonstrate that to achieve the ductility that you plan to study, the experimental test pieces have to be designed very carefully [1]. Otherwise non-ductile failure modes will intervene. The same is true for the design of buildings: although Codes of Practice are today worded with the intention of ensuring that ductile behaviour occurs, there are many ways in which non-ductile failure modes can occur. In the Codes for design against earthquake loads this is a particular problem, because the ability of structures to survive the extreme (say 500year) earthquake depends on their ability to display considerable ductility: this applies to the structure as a whole and also to members and connections. Where unintended non-ductile failure modes can occur, collapse at a ground shaking intensity much lower than the design intensity is possible. Thus detailing rules to ensure ductility are today found in all seismic codes.

A relatively recent extension of the analytical procedures proposed in codes for new buildings is to adapt them for the assessment (and strengthening) of existing buildings, and they have become the basis of methods for estimating post-earthquake losses which are today widely used in the insurance industry, and for urban risk mitigation programmes. The areas to which these methods are applied often contain (or largely consist of reinforced concrete apartment buildings which were built either before today's "ductile" codes were introduced, or without benefit of them.

However, evidence from the performance of reinforced concrete structures in the earthquakes of the last 25 years indicates that failure very commonly (if not usually) occurs in a non-ductile manner which makes such calculated vulnerability approaches inappropriate and misleading.

The paper discusses the performance of reinforced concrete buildings in recent earthquakes and compares this with the expectations of the calculated vulnerability models commonly in use.

\section{LOSS ESTIMATION APPROACHES}

On around $10 \%$ of the earth's land surface, according to the GSHAP map [2], there is a 10\% risk of occurrence in 50 years of heavy earthquake ground shaking, here defined as a peak ground acceleration around $0.32 \mathrm{~g}$ or greater. If we assume that the global population distribution is in line with the seismic hazard distribution, there may be about 600 million inhabitants in these zones, of whom, again roughly, 50\% today live in urban areas. In the developing world these urban areas are growing very rapidly, and, almost everywhere, the standard type of dwelling is either low-rise masonry, or a multi-storey reinforced concrete apartment block. As many as 50 million may today live in reinforced concrete apartment blocks, the vast majority of which are speculatively built with little or no input from an engineer, using very poor construction standards, with no application of a code of practice or design rules, and with no effective building control. 
After the Spitak earthquake, an epidemiological study [3] showed that the inhabitants of mid-rise apartment blocks there (rather better built under the Soviet regime of the time than in many such growing cities worldwide) were 40 times more likely to be killed in the earthquake than inhabitants of low-rise buildings. As the world urbanises, the risks of a major urban disaster are rapidly increasing.

Recognising this national governments and the World Bank have been attempting to launch compulsory national earthquake insurance programmes, so that the potentially losses can be transferred to the international insurance and reinsurance markets. Turkey, Romania and Algeria already have such schemes. To ensure that adequate reinsurance is available, and to set appropriate insurance rates, the modelling of the probable losses from earthquakes affecting countries and cities at risk is vital, and is today a major activity within insurance and reinsurance companies and brokers, and several specialist risk modelling companies (such as RMS and EQE) have emerged.

Typically, the approach to the development of loss estimation for the insurance industry is based on scenario studies. In this approach a large number of hypothetical earthquakes are considered, each causing ground shaking over a wide area with a geographical distribution of intensity appropriate to the magnitude and location of the assumed earthquake source, tectonic regime, and soil conditions. For each level of ground shaking a damage distribution is derived from vulnerability or fragility relationships, using a knowledge of (or assumption about) the inventory of buildings in the affected area and their distribution into different vulnerability classes. Expected losses and human casualties and other earthquake consequences are then derived from the building damage distribution. A diagrammatic representation of such a scenario study is shown in Fig 1. From a large number of such scenarios, each characterised by an annual probability of exceedence, a loss exceedence probability curve can be prepared, which will be the basis for insurance premium rates and the planning of reinsurance.

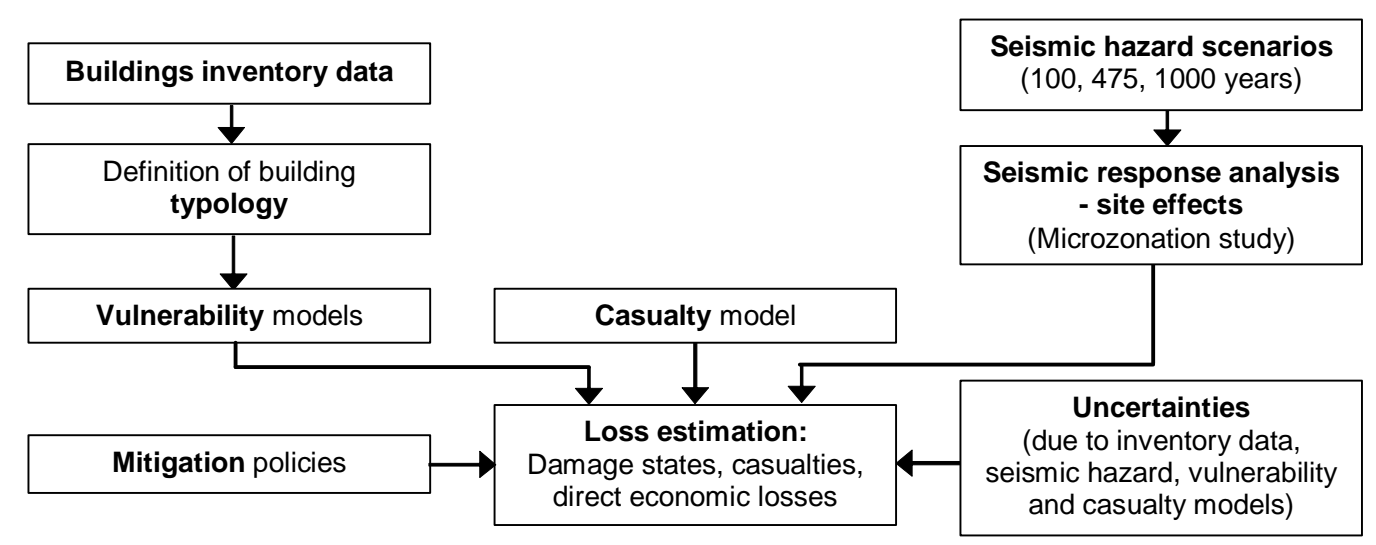

Fig 1 Diagrammatic representation of earthquake loss modelling process

Within such a process, there are essentially two alternative approaches to the vulnerability aspect of the modelling of earthquake losses which can be referred to as observed vulnerability, and calculated vulnerability. Observed vulnerability refers to assessment based primarily on past earthquake damage data. Calculated vulnerability refers to the assessment of expected performance of buildings based on calculated performance and design specifications. Neither method is fully satisfactory, and there is a continuing debate amongst loss modellers as to which approach should be adopted.

In principle, observed vulnerability is straightforward. It is an extension of the centuries-old practice of actuaries who typically have used previous loss data to set expected loss rates for the future. The usual approach is to base ground motion mapping on the well-established macroseismic intensity scales [4], as these are always mapped after an earthquake event, and localised damage surveys can therefore always be allocated to an intensity level, and thus loss-distributions for different classes of construction (load-bearing masonry, RC of various age-bands or numbers of stories) can be prepared, such as that of Table 1. 
Table 1 Damage Probability Vulnerability Matrix for Stone Masonry Buildings in Italy

\begin{tabular}{|c|c|c|c|c|c|c|c|}
\hline \multirow{2}{*}{\multicolumn{2}{|c|}{ Damage state }} & \multicolumn{6}{|c|}{ Intensity (EMS) } \\
\hline & & \multirow{2}{*}{$\frac{\text { V }}{90.4 \%}$} & \multirow{2}{*}{\begin{tabular}{|c|} 
V1 \\
$18.8 \%$ \\
\end{tabular}} & \multirow{2}{*}{\begin{tabular}{|c|} 
VII \\
$6.4 \%$ \\
\end{tabular}} & \multirow{2}{*}{$\begin{array}{c}\text { VIII } \\
0.1 \% \\
\end{array}$} & \multirow{2}{*}{$\begin{array}{c}\text { IX } \\
0.0 \% \\
\end{array}$} & \multirow{2}{*}{$\begin{array}{c}\mathbf{X} \\
0.0 \%\end{array}$} \\
\hline D0 & No damage & & & & & & \\
\hline D1 & Slight damage & $9.2 \%$ & $37.3 \%$ & $23.4 \%$ & $1.8 \%$ & $0.2 \%$ & $0.0 \%$ \\
\hline D2 & $\begin{array}{c}\text { Moderate } \\
\text { damage }\end{array}$ & $0.4 \%$ & $29.6 \%$ & $34.4 \%$ & $10.0 \%$ & $2.0 \%$ & $0.4 \%$ \\
\hline D3 & $\begin{array}{l}\text { Substantial to } \\
\text { heavy damage }\end{array}$ & $0.0 \%$ & $11.7 \%$ & $25.2 \%$ & $27.8 \%$ & $12.5 \%$ & $4.7 \%$ \\
\hline D4 & $\begin{array}{c}\text { Very heavy } \\
\text { damage }\end{array}$ & $0.0 \%$ & $2.3 \%$ & $9.2 \%$ & $38.7 \%$ & $38.3 \%$ & $27.9 \%$ \\
\hline D5 & Destruction & $0.0 \%$ & $0.2 \%$ & $1.4 \%$ & $21.6 \%$ & $47.0 \%$ & $67.0 \%$ \\
\hline
\end{tabular}

There are several limitations to this approach in practice however. One is that the method cannot be used for newer buildings, built to more recent codes, for which historic damage data does not exist. A second, more basic problem is that the macroseismic intensity scale level is partly derived from measure of building damage, making the relationship of one to the other more an interpretation of the scale than a measure of the performance of particular classes of building. A further limitation is that a single parameter of ground motion cannot satisfactorily capture the complex relationship between ground motion, subsoil and structural behaviour which is needed to predict the performance of any but the most basic of building classes. Another limitation is that loss estimation needs to consider the small possibility of occurrence of intensity XI or perhaps even XII, events of such a level of ground shaking that they have hardly ever been observed, and thus for which no satisfactory damage data is available; extrapolations commonly used to overcome this problem in loss estimation therefore have no basis. For these reasons this method is more suitable for use with non-engineered structures made with low-strength materials such as timber or unreinforced masonry at moderate intensities (up to IX), whose earthquake performance is difficult to calculate, but for which substantial statistical damage data may be available; the approach less suitable for more complex engineered structures and for higher intensities..

Some of the limitations of the observed vulnerability approaches can, in principle, be avoided by the use of calculated vulnerability, and this approach has been extensively promoted by earthquake engineers as the best way forward. Advantages are that ground motion can be defined in as complex a way as the structure demands, and is clearly independent of structure type and performance; the interaction of subsoil and structure can be modelled; and no earthquake damage history is required for a vulnerability assessment to be done. But determining the correct modelling approach is clearly essential. Linear analytical methods, still very commonly used in design, are clearly not appropriate, as they cannot predict post-yield or degradation behaviour. On the other hand non-linear dynamic time-history analysis is too time consuming to be considered for a portfolio of many structures with wide differences. An intermediate approach is the use of a non-linear static "pushover" method, which although an approximate method, does allow post-yield performance of the structure to be traced, and is able to predict a "performance point", i.e post-earthquake damage state of the structure, in response to any earthquake demand defined as a response spectrum. The most widely used approach is referred to as the "Capacity Spectrum Approach", originally designed to enable structures to be designed with multiple performance objectives, but adapted for the assessment and strengthening of existing buildings by ATC [5]. In this approach, at its simplest, the intersection of a capacity (pushover) curve with a response spectrum reduced to allow structural damping is used to determine a performance point of displacement or interstorey drift. The approach is illustrated in Fig 2.

This approach has now been adopted widely in the United States as a component of FEMA's HAZUS loss estimation methodology [6], [7]. Following its application in HAZUS, a similar approach has been used in many loss-estimation studies for countries outside the United States (eg in Turkey, [8]. 
Fig 2a. Performance point at intersection of demand and capacity curve: capacity curve using bilinear approximation

Fig 2b. Fragility curves for 4 damage states

Fig 2c Damage distribution corresponding to the performance point in Fig $2 \mathrm{a}$ and fragility curves in Fig $2 b$

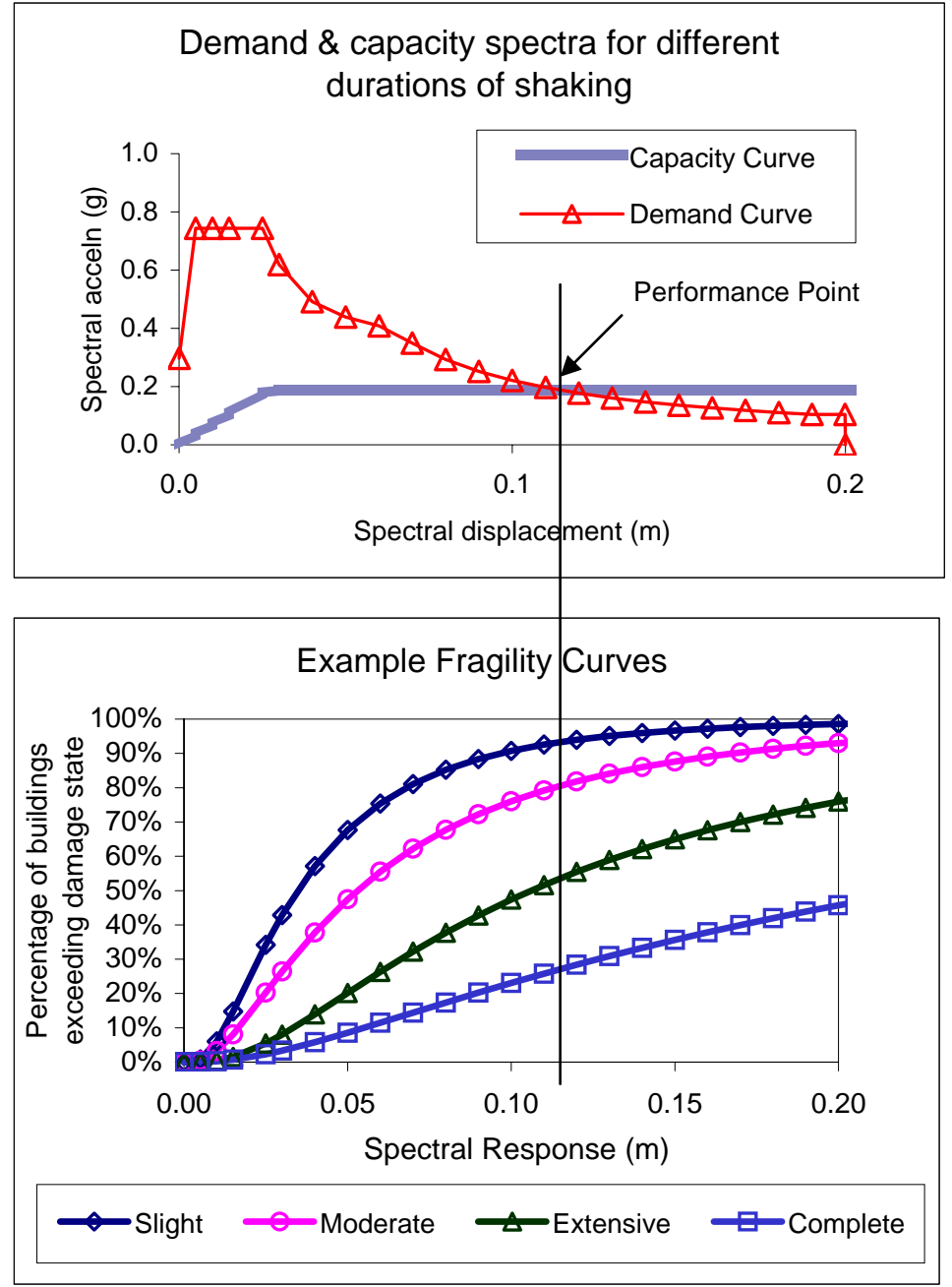

Percentage of damaged buildings in damage states

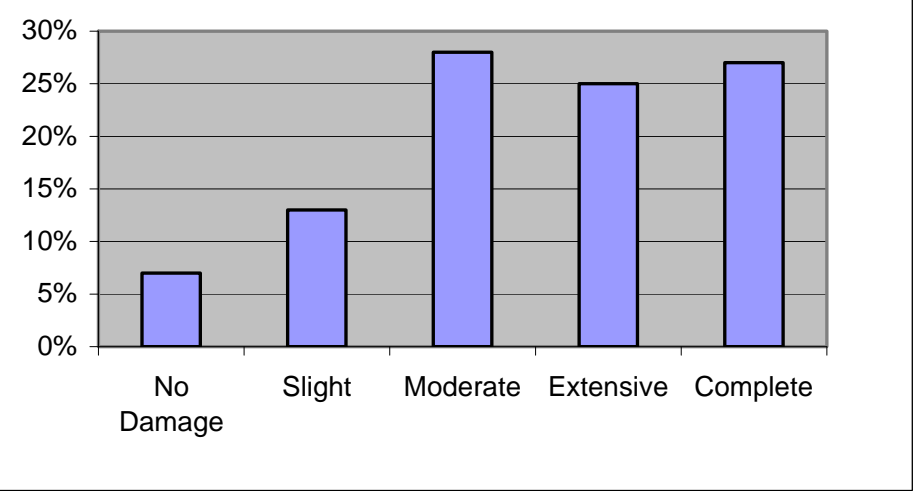

Fig. 2. An overview of the Capacity Spectrum (HAZUS) approach to loss estimation

A somewhat similar approach [9] achieves the same result, but uses a direct relationship of structural deformation to moment-rotation relationships at the key beam-column joints to define a displacement demand for a given seismic motion.

Using either of these approaches, the result is an estimated structural response for one single building with a given set of performance parameters, and the application to a class of buildings (of similar structural form but with different dimensions detailing etc) is achieved through fragility curves 
(Fig $2 \mathrm{~b}$ ) by means of which a single estimated performance displacement is converted to a damage distribution (ie a probability distribution of different damage states, Fig 2c). From the predicted damage distribution, the losses (financial and human) associated with the ground shaking are estimated in the same way as for the observed vulnerability approach.

In principle this method is satisfactory for a wide range of "engineered" structures for which a calculated pushover curve is possible. However, the key question which needs to be answered before the method can be satisfactorily adopted for loss-estimation is whether the model of structural performance on which it is based is a satisfactory approximation to the way actual structures behave in real earthquakes. In particular, do structures seriously damaged by earthquakes display the kind of displacement behaviour represented in the model by means of the pushover curve. The intention of this paper is to approach this question through an examination of the performance of reinforced concrete structures in some recent earthquakes.

\section{OBSERVED PERFORMANCE OF REINFORCED CONCRETE BUILDINGS IN EARTHQUAKES}

There is a great deal of descriptive data available on the performance of reinforced concrete structures, through the reports of reconnaissance teams both in the UK (EEFIT) and in the United States (EERI). The author was personally involved in EEFIT reconnaissance missions in Italy (Irpinia earthquake, 1980 and Umbia-Marche earthquake, 1997), Turkey (Kocaeli earthquake 1999), India (Bhuj earthquake, 2001), and Pakistan (Kashmir earthquake, 2005), and these earthquakes will form the basis of the investigation. Some other earthquakes will also be considered.

There were many similarities in the reinforced concrete buildings which were affected by all of these earthquakes. Most of them were multi-storey reinforced concrete frame apartment buildings, with infill panels within the frame made of relatively poor quality masonry blocks. Concrete shear walls providing a robust lateral-load resisting system were rare, and columns were typically weaker in moment-capacity than beams. A common feature of many buildings was a relatively open ground floor to provide for commercial space or car-parking, with infill walls omitted, and often with a larger storeyheight than upper stories. Post-earthquake investigations found that many of these buildings had been designed for gravity and nominal lateral loads only. Close juxtaposition of adjacent buildings was common.
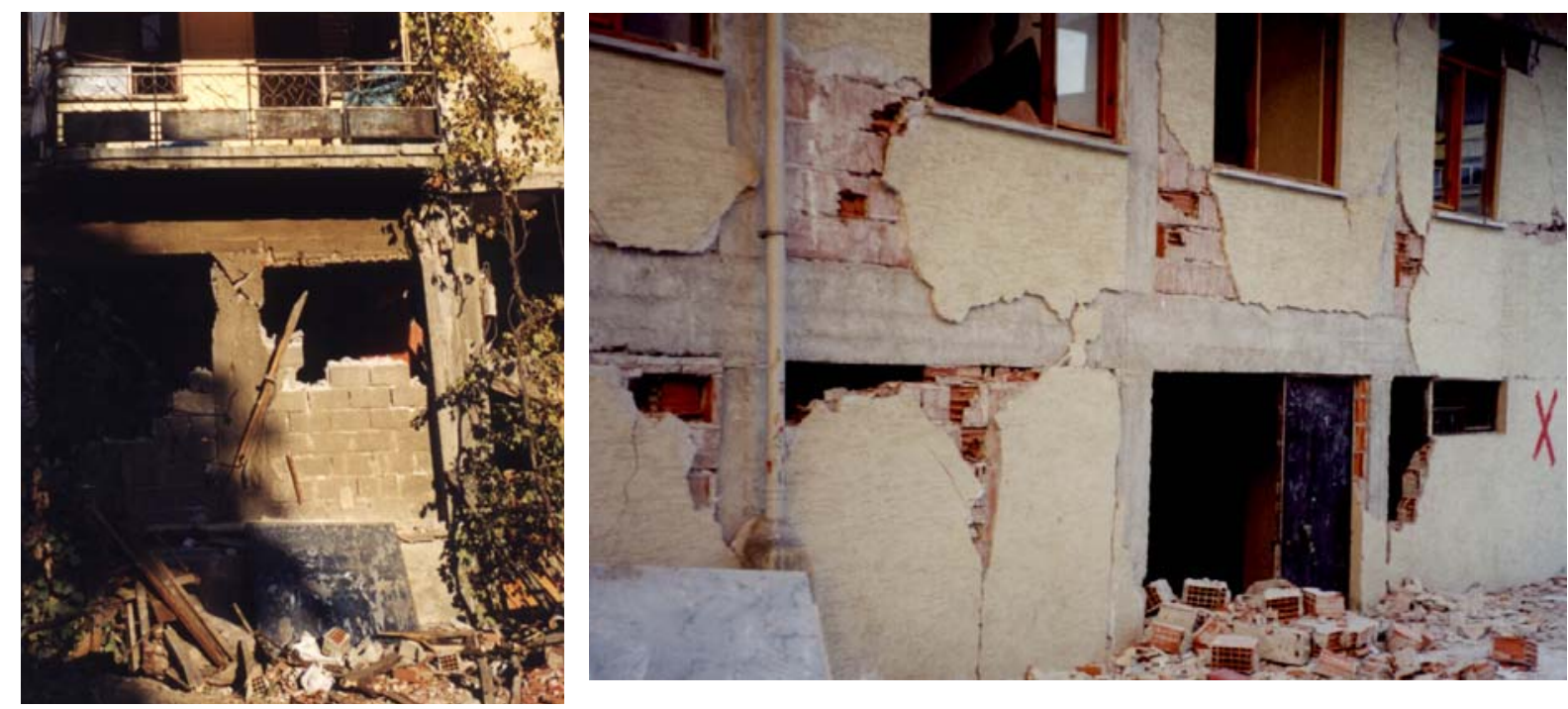

Figures 3 and 4. Effects of infill walls on reinforced concrete frame behaviour: 1999 Kocaeli earthquake, (Author's photos)

The most detailed damage surveys were carried out after the Kocaeli earthquake [10], [11]. In this earthquake building damage was mainly concentrated in reinforced concrete buildings. Reconnaissance missions identified a wide range of types of collapse and localised failure. Multiple storey collapses and lower floor collapses were very common: although after a catastrophic failure has occurred the precise cause is often difficult to identify, these are thought to have mostly been triggered by failure at the tops and bottoms of the relatively weak columns. Because of poor detailing of reinforcement and poor quality of concrete, plastic rotation capacities in the beam-column joints will 
have been very limited indeed, and numerous examples of failed column joints were also observable in buildings which did not totally collapse. Often these displayed crushing of the concrete, inadequately confined by shear reinforcement. Thin rectangular columns with a wide disparity in stiffness between their two perpendicular directions were common, leading to torsional affects and to column shear failures. Shear failures also occurred as a result of the interaction of the frame with the infill walls (Figs 3,4). Further shear failures occurred as a result of pounding between adjacent buildings. Precast concrete buildings also performed poorly, with failures commonly located at the joints.

Various separate investigations [10], [11] blamed poor quality materials (especially concrete), poor design concepts and detailing and "glaring contraventions of adequate earthquake resistance" as being responsible for the poor performance of reinforced concrete buildings in this earthquake. Remarkably, although the Turkish design Code for building in earthquake areas is good and up to date, the collapse rate of buildings built after 1975 was worse than those built earlier, and the performance of masonry buildings (many of traditional himis timber-laced construction) was better than either. Langenbach [12], commenting on the damage pattern in the Kocaeli earthquake, observed that:

"The traditional buildings that survived the earthquake were not engineered and lacked steel or concrete. ... they were constructed with a minimum of tools with locally acquired materials, using a minimum of costly resources ... Thus, the traditional buildings possess the kind of deficiencies in construction quality that are identified as reasons why the modern buildings fell down, yet they remained standing. It appears that we have one system constructed with the full benefit of strong materials that is subject to catastrophic failure in large seismic events if it deviates from a sophisticated level of design and construction perfection, while we have another constructed of comparatively weak materials by relatively untrained craftsmen that is, with few exceptions, robust enough to withstand major earthquakes."

Following the Bhuj earthquake in 2001, investigations identified an almost exactly analogous set of deficiencies, in structural arrangement, materials, detailing and use of earthquake codes [13] applicable to reinforced concrete apartment blocks throughout the affected area. Ground floor collapses, and shear failures in columns were once again common. In Ahmedabad, some $250 \mathrm{~km}$ from the epicentre, as many as 130 buildings collapsed, all of them of reinforced concrete frame construction, and mostly with open ground floors. (Figs 5,6) Special forms of failure were the destruction of columns by relatively rigid metal shutters which were down at the time of the earthquake (a public holiday), and the collapse of water tanks inadequately supported on roofs. A standard pushover analysis was performed on two existing buildings which had been slightly damaged in the earthquake, [13] (Fig 7). This showed that failure would occur in a brittle manner by means of successive shear failures in the ground floor columns at loads well below the design expectation, and also at a very low value of interstorey drift (between 0.5 and $1 \%$ at ultimate limit state).
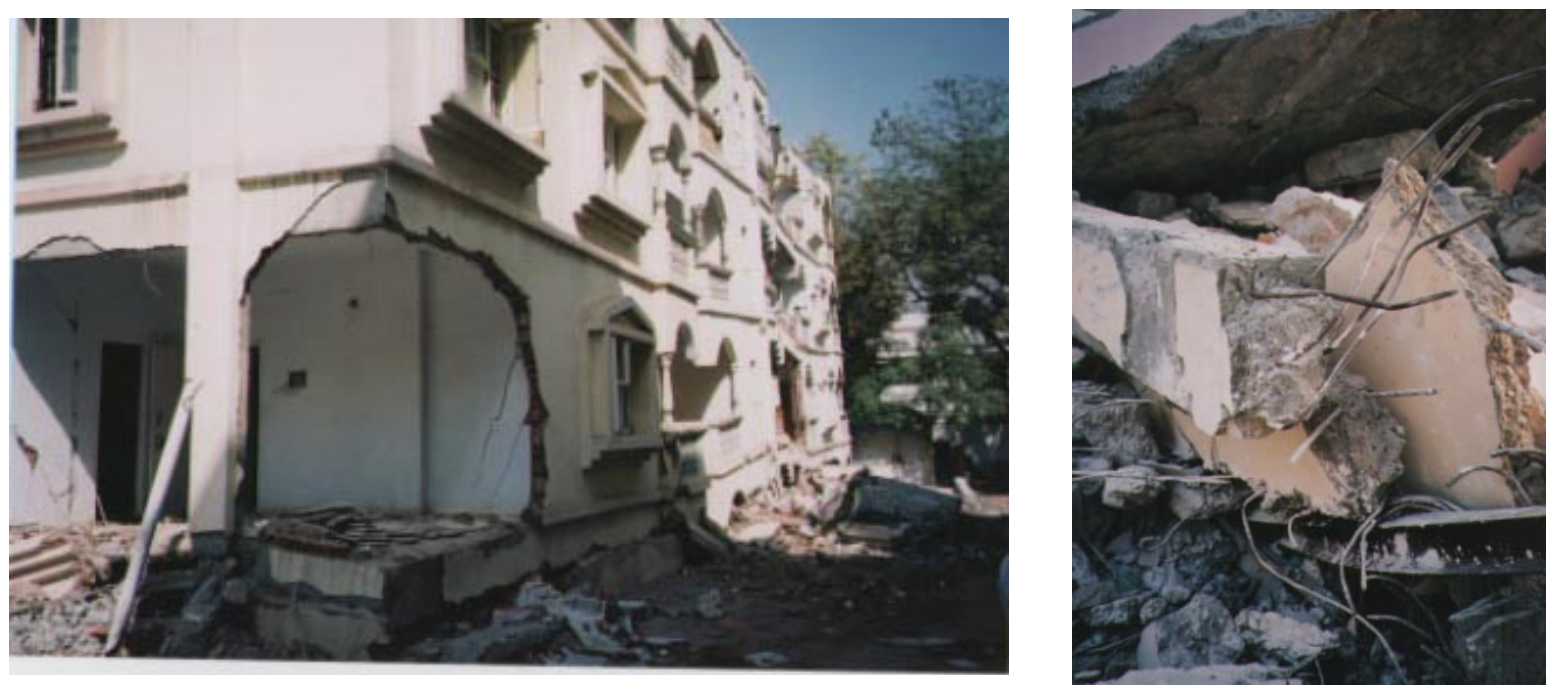

Figs 5 and 6 Loss of ground floor in a multi-storey building, and lack of reinforcement in failed column: Bhuj earthquake, India, 1999 (Author's photos) 


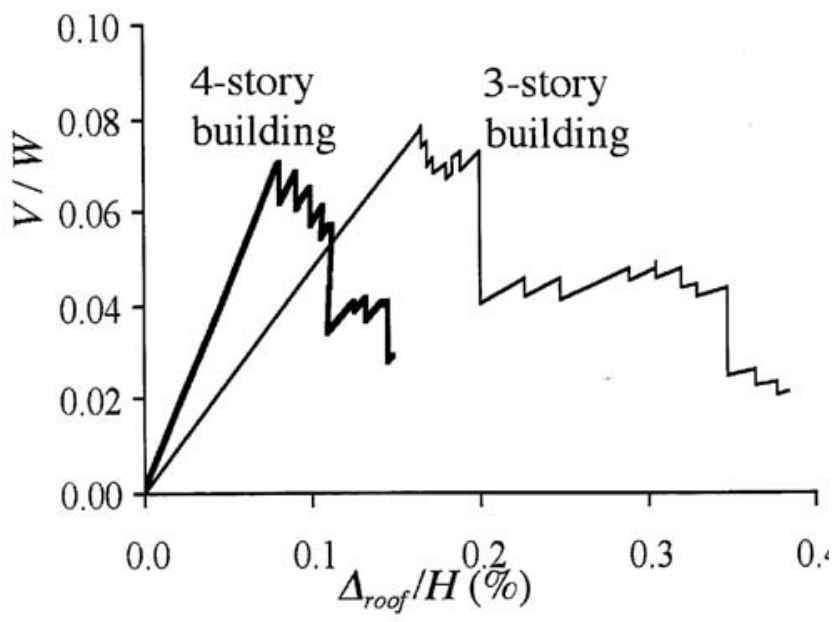

Fig 7. Pushover curves for two reinforced concrete frame buildings slightly damaged by the 2001 Bhuj earthquake (after EERI, 11])

Observations in many of the other earthquakes which have affected reinforced concrete frame buildings are quite similar [14], [15]. A special case was the $M=6.8$ Armenia earthquake of 7.12.1988 in the then Soviet Union [16] in which 25,000 people died. Spitak was a relatively recently-built town, with many modern multi-storey apartment blocks. Some of these were of composite RC frame-stone buildings (up to 5 storeys), others were 9-storey precast concrete frame buildings or precast concrete panel buildings. In Spitak, $87 \%$ of the structures collapsed or suffered such heavy damage that they had to be demolished. Even in Leninakan about $30 \%$ of the engineered structures suffered heavy damage, and 72 9-storey precast concrete frame buildings (95\% of the total) collapsed. Many died in these apartment blocks. By contrast, the precast concrete panel buildings performed well, and not one of them collapsed [16].

\section{DISCUSSION}

The vital role of ductility in providing resistance to earthquake ground shaking has been explained earlier. As Mo [17] puts it, even when the earthquake demand is within that provided for in the Code:

"The problem is that the code lateral forces may be exceeded during actual earthquakes and the unit deformations associated with the yield point may be greatly exceeded. The performance of the structure then depends on its properties beyond the initial yield point. If there is no ductility and there is no alternative stress path, the structure collapses under continued earthquake demands. On the other hand ductility and reserve inelastic energy capacity... may be available and may save the structure"

It is clear from the post-earthquake reconnaissance reports discussed above that many if not most of the failed buildings have failed in a non-ductile or brittle fashion. Even among those which have failed through a classical sway mechanism, evidence suggests that poor design of beam column joints has resulted in rapid degradation after first overload, and little ductility. The relative absence of buildings which were left after the earthquake in a displaced but not collapsed condition reinforces this conclusion.

In the areas investigated in detail through the post-earthquake reconnaissance missions, it is almost certain that the same lack of ductility is very widespread, even amongst buildings which did not fail. The reports suggest that many were saved through the action of infill masonry walls not allowed for in the design, or simply through local variations in the level and type of ground shaking.

More speculatively, it is possible to infer that the types of post-earthquake behaviour observed in India and Turkey in recent earthquakes are likely to be repeated in the event of heavy ground shaking in most cities where reinforced concrete apartment blocks of similar form have been constructed 
without respecting a modern earthquake code, that is, in a great many of the world's most rapidly developing cities.

The discrepancy between this actual earthquake behaviour and the type of behaviour assumed in the capacity-spectrum and other analytical procedures for assessing earthquake performance of existing structures is very striking. Although a brittle structure which suffers a dramatic loss of strength before or soon after yielding and then collapses can perfectly well be modelled by the capacity spectrum approach [18], this is not the assumption built into the way the models are actually used. On the contrary, the models tend to assume a substantial measure of ductile behaviour and estimate the damage state based on that assumption. In reality, the failed structures behave in a brittle manner. Moreover, a single degree of freedom system (SDOF) model of the type needed for capacity spectrum analysis cannot allow for time (rather than displacement-) dependent degradation effects that might occur (for example) due to progressive crushing of infill walls, shear cracking in a column hinge, bond slip in bars and so on [19].

For use in urban loss estimation studies there is a need for improved analytical models which can be used to investigate the wide range of brittle failure modes which may occur, and basing loss estimates on a combination of alternative modelling assumptions. Such models will need to take account of progressive deterioration of the critical joints in the frame the important contribution of infill walls to behaviour of reinforced concrete frame structures.

Such models will be urgently needed to support the envisaged expansion of earthquake insurance schemes and urban mitigation programmes, as well as to provide realistic estimates of numbers of casualties and homeless people following future large earthquake events. In the absence of valid and tested models, it will continue to be necessary to rely on statistical approaches to damage and loss estimation for this class of building, based on damage surveys in recent earthquakes, given that it constitutes a very significant part of the earthquake losses which can be expected in the immediate future. Meanwhile a degree of validation of existing calculated approaches using the existing damage data coupled with new estimates of the causative ground motion can begin to reconcile the two approaches.

\section{CONCLUSIONS}

From this brief overview it is concluded that

0 there is an urgent need for the development of a calculated approach to loss estimation to overcome the problems inherent in statistical approaches based solely on observed damage data

o current calculated loss estimation procedures are based on assumptions that may be appropriate to buildings designed to recent "ductile" codes, but are not appropriate to the mass of large reinforced concrete buildings in existence (and today being constructed) which may be subjected to heavy ground shaking, and thus

o further development of models which can adequately represent real structures in vulnerable locations, and particularly their inherently non-ductile modes of earthquake response is now required

o in the absence of such models, reliance will need to continue to be placed on statistically based approaches based on observed damage.

\section{ACKNOWLEDGEMENTS}

With thanks to Chris Morley for inspiring my interest in the performance of reinforced concrete, and to Chris Burgoyne and Edmund Booth for reviewing the manuscript and making a number of helpful suggestions for improvement. 


\section{REFERENCES}

[1] Morley C.T. and Spence. R.J.S. "The strength of single cell concrete box girders of deformable cross-section", Proceedings of the Institution of Civil Engineers, Part 2, 59, pp. 743-761, December 1975.

[2] Grünthal, G, Bosse, C, Sellami, S, Mayer-Rosa, D and Giardini, D, 1999. Compilation of the GSHAP regional seismic hazard for Europe, Africa and the Middle East, http://seismo.ethz.ch/GSHAP

[3] Armenian, H.K, Melkonian, A, Noji E, and Hovanesian, P 1997. "Deaths and Injuries due to the Earthquake in Armenia: a Cohort Approach", International Journal of Epidemiology, Vol 26, 4, pp806-813.

[4] Grünthal, G, (ed) 1998. European Macroseismic Scale 1998 (EMS 1998), Council of Europe, Cahiers du Centre Europeen de Geodynamique et du Seismologie, Vol 15, ISBN 2 87977-0084

[5] Applied Technology Council, 1996. Seismic Evaluation and Retrofit of Concrete Buildings, ATC40, ATC, Redwood City CA

[6] FEMA, 1999. HAZUS, 1999, Earthquake Loss Estimation Methodology, US Federal Emergency Management Agency, (www.fema.org)

[7] Kircher, C.A, Nassar, A.A, Kustu, O, and Holmes, W.T, 1997. "Development of building damage functions for earthquake loss estimation" Earthquake Spectra, 13, 4, pp 663-682.

[8] Bommer, J. Spence R. , Tabuchi, S. Aydinoglu, N. Booth, E. del Re, D. Erdik, M. Peterken O., 2002. "Development of an Earthquake Loss Model for Turkish Catastrophe Insurance" Special Issue of the Journal of Seismology on the Turkish Earthquakes of 1999, Vol 6, no 2, 2002. vol 6, no. 2 pp 431-446, ISSN 1383-4649

[9] Crowley, H, Pinho, R, Bommer, J.J and Bird, J.F, 2006. Development of a Displacement-Based Method for Earthquake Loss Assessment, IUSS Press, University of Pavia

[10] D'Ayala, D, Doyle, P, and Spence, R, 2003. "Chapter 5, Performance of Buildings" in D'Ayala (ed) The Kocaeli Turkey Earthquake of 17 August 1999: A Field Report by EEFIT, Institution of Structural Engineers, London, ISBN 0901279283

[11] Youd, T.L, Bardet, J-P, and Bray, J.D (eds,) 2000. Kocaeli, Turkey, Earthquake of August 17, 1999, Reconnaissance Report, Earthquake Spectra, Special Publication 2000-03, EERI

[12] Langenbach, 2006. "Preventing Pancake Collapse: Lessons from Earthquake-Resistant Traditional Construction for Modern Buildings of Reinforced Concrete". International Disaster Reduction Conference, Davos Switzerland, 2006.

[13] Jain, S, Lettis, W.R, Murty, C and Bardet, J-P (eds), 2002. Bhuj India Earthquake of January $26^{\text {th }}$ 2001: Reconnaissance Report, Earthquake Spectra, Publication No 2002-01.

[14] EEFIT, 1992. The Erzincan, Turkey Earthquake of 13 March 1992: a Field Report by EEFIT, Institution of Structural Engineers, London

[15] EERI, 1981. Earthquake in Campania-Basilicata, Italy November 23, 1980: a Reconnaissance Report, National Academy Press, Washington DC

[16] Wyllie, L and Filson, J (eds), 1989 Armenia Earthquake Reconnaissance Report, Earthquake Spectra, Special Supplement, August 1989, EERI.

[17] Mo, Y.L. 2003. Chapter 13, Reinforced Concrete Structures in Scawthorn C, and Chen, W-F (eds), Earthquake Engineering Handbook, CRC Press, New York

[18] Booth, Spence and Bird, 2004. "Building vulnerability assessment using pushover methods - a Turkish case study" Proceedings of international workshop on Performance-based seismic design, Bled Slovenia.

[19] Edmund Booth (personal communication) 
